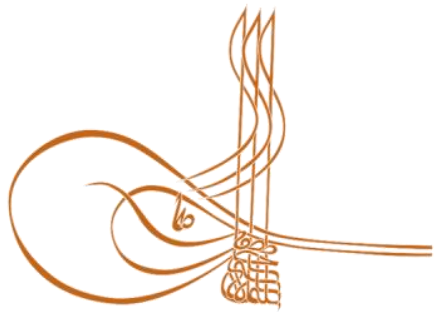

www.turkishstudies.net/language
Turkish Studies - Language and Literature

eISSN: 2667-5641

Research Article / Araștırma Makalesi

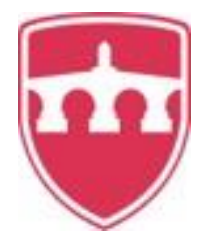

INTERNATIONAL

BALKAN

UNIVERSITY

Sponsored by IBU

\title{
Batı Karadeniz Bölgesi Ağızları ile Eski Anadolu Türkçesindeki Eklerin Ünlü Yuvarlaklaşması Yönünden Karşılaştırılması
}

\author{
Comparing Suffixes in Western Black Sea Region Dialects and Old Natolian Turkish in Terms of \\ Vowel Rounding
}

\author{
Burak Telli*
}

\begin{abstract}
The most prominent period in terms of the vowel rounding of the Turkish period is the Old Anatolian Turkish period. Even the annexes related to lip harmony in Old Turkish remained out of lip harmony due to the rounding of vowels in Old Anatolian Turkish period. This phonetic phenomenon is so common in Old Anatolian Turkish that it has become a characteristic feature of the period. With the beginning of the Ottoman Turkish period from the 15th century, this powerful phonetic event began to diminish; but spelling continued its influence until the 18th century. As a historical period, there was not a rounding that would disrupt the harmony of the lip before and after itself, and the fact that this powerful phonetic event was seen in Old Anatolian Turkish stems from the dialect feature of the Oghuz tribes who established the written language in Anatolia. The dialects living in Anatolia today are the result of this historical process. Each of the different dialect features seen in various regions of Anatolia is a remnant of the dialects of the Oghuz tribes who settled in this geography in the historical period. Rounding, which is the characteristic feature of Old Anatolian Turkish, also manifests itself in Anatolian dialects today. Bolu, Kastamonu, Zonguldak, Karabuk, Bartin, Sinop, such as the settlement of the Western Black Sea region, the vowel rounding of the dialect is widely seen. In this study, Western Black Sea region dialects and Old Anatolian Turkish suffixes will be evaluated in terms of vowel rounding. During the evaluation, Old Anatolian Turkish will be taken to the center. In this period, the consistency of the annexes used in the continuous round vowels and continuous vowels in the Western Black Sea region will be presented comparatively. In addition, data will be tried to be obtained about the oral effect of the establishment of Old Anatolian Turkish.
\end{abstract}

Structured Abstract: Turkish sound structure has a strong vowel harmony. Even in the first examples that we can follow through the texts, there is a strong vowel harmony. Especially in this sense, the harmony of thickness and thinness shows itself in all the texts from the oldest periods to the present. For this reason, non-compliance in Turkish words in terms of thickness-thinness is almost non-existent.

\footnotetext{
* Dr. Öğr. Üyesi, Kahramanmaraş Sütçü İmam Üniversitesi, Fen-Edebiyat Fakültesi, Türk Dili ve Edebiyatı Bölümü, Yeni Türk Dili Ana Bilim Dalı.

Assist Prof. Dr., Kahramanmaras Sutcu Imam University, Faculty of Science and Letters, Department of Turkish Language and Literature, New Turkish Language.

ORCID 0000-0003-4924-9205

btelli46@gmail.com
}

Cite as/ Atıf: Telli, B. (2020). Batı Karadeniz Bölgesi ağızları ile Eski Anadolu Türkçesindeki eklerin ünlü yuvarlaklaşması yönünden karşılaştırılması, Turkish Studies - Language, 15(1), 425-441. https://dx.doi.org/10.29228/TurkishStudies.40602

Received/Geliş: 16 January/Ocak 2020

Accepted/Kabul: 25 March/Mart 2020

Copyright (C) INTAC LTD, Turkey 
The other harmony with vowels is the flatness-roundness harmony. After the sounds a, e, i, i, one of the sounds a, e, i, i in the following syllable; o, ö, u, ü sounds after the flat-wide a, e or narrow-round $u$, $\ddot{u}$ is the rule of one of the sounds. This harmony, also called lip harmony or small vowel harmony, is not as dominant as the thickness-thinness harmony. It is seen that lip harmony is especially strong in the annexes in the Turkish period.

In the Old Turkish period, the annexes related to lip harmony were largely out of lip harmony in Old Anatolian Turkish. In fact, this situation has become a characteristic feature of Old Anatolian Turkish.

Lip mismatch, which was observed intensively in this period, continued for a long time in Ottoman Turkish after the continuation of Old Anatolian Turkish. This lip mismatch continued in the 16th century. It is estimated that a transitional period began in the late 16th century and lip harmony was reached in the 18 th century.

In our study, while comparing the suffixes in the dialects of Old Anatolian Turkish and Western Black Sea region, we have classified them as the annexes used in the continuous round vowel and the continuous vowel used in the Old Anatolian Turkish.

Today, the emergence of different dialect features in the Anatolian geography is undoubtedly due to the cultural richness and difference in the establishment of the Old Anatolian Turkish written language. The Oghuz tribes that settled in the Anatolian geography since the 11th century have carried their dialect differences to Anatolia and have contributed to the formation of today's accents. The dialect features of the Western Black Sea region also show great similarity with the Old Anatolian Turkish in terms of lip compatibility of the annexes. In particular, we emphasize adds some review section, the use of Turkey in Turkish literary language today is the same with the use of completely different and Old Anatolian Turkish. The similarity of the vowel roundness seen between the dialects of Old Anatolian Turkish and the Western Black Sea region was the starting point of this study.

The presence of the features of the Western Black Sea Region in common with Old Anatolian Turkish will give an opportunity to evaluate the relation between written language and dialect in the establishment of Old Anatolian Turkish. In the region, especially in Bolu, Kastamonu dialects, both the roots of the word and the suffixes are dominated by vowel rounding. There are of course different dialect areas within the Western Group dialects where there is a vowel rounding. In this study, Western Black Sea region was determined as a geography where rounding was seen intensively and the annexes in this region dialects were compared with Old Anatolian Turkish in terms of vowel rounding.

Dialects are very important language treasures which are the source of language studies. Many phonetic features, morphological structures and vocabulary elements that are not present in the written language, but we know that they existed in historical periods, can still exist in the dialects today. Therefore, there is a close relationship between dialects and historical periods in language studies.

Old Anatolian Turkish is the period during which the vowel rounding of Turkish is seen most. When the inserts used with continuous round vowels are added to the flat vowel bases, the lip fit is deteriorated. For this reason, lip harmony in Old Anatolian Turkish is at a very low level. This feature of the period can be seen today at the dialects of the Western Black Sea region. Bolu, Duzce, Kastamonu, Zonguldak, Bartin, Karabuk and Sinop are located in the region. In fact, some suffixes used in Old Anatolian Turkish with flat vowels were found to be used in the dialects of the Western Black Sea region in a round shape except for lip harmony.

The number of annexes used with round vowels was found to be 16 in both Anatolian and Western Black Sea regions. Not all of these 16 inserts have round vowels in the entire dialect; however, it is generally seen as a round vowel. 7 annexes are used in Old Anatolian Turkish, while the vowel is used in the Western Black Sea region.

Both the Old Anatolian Turkish and Western Black Sea region dialects with round vowels identified round vowels are used throughout the region: +lU noun production suffix, + sUz noun production suffix, -Ur wide-time suffix and -Uz first multitude suffix. Bolu and Kastamonu dialects are the places where the round vowels are most commonly seen in the region.

The use of the past tense suffix learned with the suffix +llk from the suffixes used in the plain Anatolian vowels in the old Anatolian Turkish, except for round vowel and lip harmony, is seen most of the dialects of 
the Western Black Sea region. The other inserts listed in this title are seen in various dialect regions, not most of the region. In Old Anatolian Turkish, the suffixes with flat vowels and round vowels are used at the dialects of the region.

When the dialects of the Western Black Sea region are examined in terms of the vowel rounding, it is seen that there is a similarity between the region dialect and Old Anatolian Turkish. In particular, the dialect of Bolu comes to the front. Of course, it is not possible to answer whether the dialect of the region contributes to the writing language of Old Anatolian Turkish by taking this feature into account. However, we believe that it will contribute at least to written language and oral studies.

Keywords: Turkish Language, Old Anatolian Turkish, Western Black Sea Region Dialects, Labial Harmony, Vowel Rounding.

Öz: Türkçenin tarihî dönemleri içerisinde ünlü yuvarlaklaması yönünden en belirgin dönem Eski Anadolu Türkçesi dönemidir. Eski Türkçede dudak uyumuna bağlı olan ekler dahi Eski Anadolu Türkçesi döneminde ünlülerinin yuvarlaklaşması sebebiyle dudak uyumu dışında kalmıştır. Bu fonetik hadise Eski Anadolu Türkçesinde o denli yaygındır ki dönemin karakteristik özelliği haline gelmiştir. 15. yüzyıldan itibaren Osmanlı Türkçesi döneminin başlaması ile bu güçlü fonetik hadise azalmaya başlamış; fakat imlâda etksini 18. yüzyıla kadar sürdürmüştür. Tarihî dönem olarak kendisinden önce ve sonra dudak uyumunu bozacak bir yuvarlaklaşma olmayıp bu güçlü fonetik hadisenin Eski Anadolu Türkçesinde görülmesi, Anadolu'da yazı dilini kuran Oğuz boylarının ağız özelliğinden kaynaklanmaktadır. Bugün Anadolu coğrafyasında yaşayan ağızlar, bu tarihî sürecin neticesi olarak bulunur. Anadolu'nun çeşitli bölgelerinde görülen farklı ağız özelliklerinin her biri, tarihî dönemde bu coğrafyaya yerleşen Oğuz boylarının ağızlarının birer kalıntısıdır. Eski Anadolu Türkçesinin karakteristik özelliği olan yuvarlaklaşma da bugün Anadolu ağılarında kendini göstermektedir. Bolu, Kastamonu, Zonguldak, Karabük, Bartın, Sinop gibi Batı Karadeniz bölgesini oluşturan yerleşim yerlerinin ağızlarında ünlü yuvarlaklaşması yaygın şekilde görülmektedir. Bu çalışmada Batı Karadeniz bölgesi ağızları ile Eski Anadolu Türkçesindeki ekler ünlü yuvarlaklaşması yönünden değerlendirilecektir. Değerlendirme yapılırken Eski Anadolu Türkçesi merkeze alınacaktır. Bu dönemde sürekli yuvarlak ünlülü ve sürekli düz ünlülü kullanılan eklerin Batı Karadeniz bölgesi ağılarındaki durumları karşılaştırmalı şekilde ortaya konacaktır. Ayrıca Eski Anadolu Türkçesinin kuruluşundaki ağız etkisi hakkında veriler elde edilmeye çalışılacaktır.

Anahtar Kelimeler: Türk Dili, Eski Anadolu Türkçesi, Batı Karadeniz Bölgesi Ağızları, Dudak Uyumu, Ünlü Yuvarlaklaşması.

\section{Giriş}

Türkçe ses yapısı yönünden güçlü bir ünlü uyumuna sahiptir. Metinlerle takip edebildiğimiz ilk örneklerde dahi büyük oranda sağlam bir ünlü uyumu söz konusudur. Özellikle kalınlık-incelik uyumu bu anlamda en eski dönemlerden günümüze kadar bütün metinlerde kendini gösterir. $\mathrm{Bu}$ sebeple Türkçe kelimelerde kalınlık-incelik yönünden uyum dışı kullanım yok denecek kadar azdır.

Ünlüler ile ilgili diğer uyum ise düzlük-yuvarlaklık uyumudur. Bu uyum $a, e, l, i$ seslerinden sonra müteakip hecede yine $a, e, l, i$ seslerinden uygun olan birinin gelmesi; $o, \ddot{o}, u$, $\ddot{u}$ seslerinden sonra ise düz-geniş $a$, $e$ ya da dar-yuvarlak $u$, $\ddot{u}$ seslerinden birinin gelmesi kuralıdır. Dudak uyumu ya da küçük ünlü uyumu da denen bu uyum, kalınlık-incelik uyumu kadar baskın bir uyum değildir. Eski Türkçe döneminde özellikle eklerde dudak uyumunun sağlam olduğu görülmektedir. Bu dönemde kelime köklerinde dudak uyumu dışında kalan kullanımlar görmek mümkündür: yort"yürümek", yinçü “inci”, tilkü "tilki”. Eski Türkçe döneminde dudak uyumuna bağli olan ekler büyük oranda Eski Anadolu Türkçesinde dudak uyumu dıșına çıkmıștır. Hatta bu durum Eski Anadolu Türkçesinin karakteristik özelliği haline gelmiş̧ir. Karahan'a göre dudak uyumunu bozan bu ünlü yuvarlaklaşması 13. yüzyıldan itibaren en az üç yüz yıl Anadolu yazı dilinin temel özelliği olmuştur (Karahan, 2006: 5). 
$\mathrm{Bu}$ dönemde yoğun şekilde görülen dudak uyumsuzluğu Eski Anadolu Türkçesinin devamında Osmanlı Türkçesinde de uzun süre devam etmiştir. Söz konusu dudak uyumsuzluğu, 16. yüzyılda da devam etmiştir. 16. yüzyılın sonlarında başlayan bir geçiş dönemiyle 18. yüzyılda dudak uyumuna ulaşıldığı tahmin edilmektedir (Ercilasun, 2005: 462). Develi ise Evliya Çelebi'nin Seyahat-namesi üzerinden 17. yüzyıl Osmanlı Türkçesindeki ses benzeşmeleri ve uyumlarını incelediği çalışmasında 17. yüzyılın kelime tabanlarında dudak uyumunun gerçekleşmesi için tam bir geçiş dönemi olduğunu söylemektedir. Ayrıca bazı kelimelerdeki söz konusu ünlülerin son zamanlara kadar $y$ (ى) ile gösterilmesine rağmen dudak uyumunun 17. yüzyılda epeyce ilerlediği hatta bazı kelimelerde tamamlanmış olduğunu dile getirmiş, eklerin ise 18. yüzyıl sonunda tam olarak dudak uyumuna girdiğini ifade etmiş̧tir (Develi, 1995: 55, 62). Kartallığlu da aynı doğrultuda eklerin 18. yüzyılın sonlarında büyük oranda bugünkü şekillerini aldığını ifade etmiştir (Kartallığlu, 2007: 87).

Eski Anadolu Türkçesinde dudak uyumuna aykırı olan epeyce ek bulunmaktadır. Bunlar ya dudak ünsüzlerinin yanlarındaki ek ünlülülerini yuvarlaklaştırmalarından ya da bir kısım eklerin ilk ses yapılarını sürdüregelmiş olmalarından kaynaklanmıştır. Ekleri bu açıdan yuvarlak ünlü taşıyan ekler ve düz ünlü taşıyan ekler olarak ikiye ayırmak gerekir (Korkmaz, 2013: 93). Çalışmamızda Eski Anadolu Türkçesi ve Batı Karadeniz bölgesi ağızlarındaki ekleri karşılaştırırken Eski Anadolu Türkçesinde sürekli yuvarlak ünlülü kullanılan ve sürekli düz ünlülü kullanılan ekler olarak tasnif ettik.

Eski Anadolu Türkçesinde dudak uyumu dışında kalan ekler Akar'a göre iki ayrı fonetik yapıya sahiptir. Bunlardan birincisi, yanında dudak ünsüzleri bulunan (+Um, +UmUz, -Up, UbAn...) ekler, ikincisi ise yanında dudak ünsüzü yer aalmayan eklerdir (-Ur, -U, -dUr...). Birinci sınıftaki ekler dudak ünsüzlerinin etkisiyle, diğerleri ise genel eğilime benzeşerek yuvarlaklaşmışlardır (Akar, 2018: 107).

Eski Anadolu Türkçesi bir yandan Osmanlı Türkçesine ve Türkiye Türkçesine uzanan bir yazı dili temelindeki gelişimini tamamlarken bir yandan da yazı dilinin baskısından uzak kalan değişim ve gelişmelerle günümüz Türkiye Türkçesi ağızlarının oluşmasına temel hazırlamıştır. Bünyesinde var olan çok çeşitli özellikler ile Türkiye Türkçesindeki ağızlarındaki zenginlik ve çeşitliliği beslemiştir (Korkmaz, 2013: 109). Bugün Anadolu coğrafyasında farklı ağız özelliklerinin oluşması, şüphesiz Eski Anadolu Türkçesi yazı dilinin kuruluşundaki kültürel zenginlik ve farklılıktan gelmektedir. 11. yüzyıldan itibaren Anadolu coğrafyasına yerleşen Oğuz boyları, kendi boyları arasındaki ağız farklılıklarını Anadolu'ya taşımışlar ve bügünkü ağızların oluşmasına kaynaklık etmişlerdir. Batı Karadeniz bölgesi ağız özellikleri de eklerin dudak uyumu özelliği yönünden Eski Anadolu Türkçesi ile büyük benzerlik göstermektedir. Özellikle inceleme bölümünde vurgulayacağımız bazı ekler, bugün Türkiye Türkçesi yazı dilindeki kullanımından tamamen farklı ve Eski Anadolu Türkçesindeki kullanımı ile aynıdır. Eski Anadolu Türkçesi ile Batı Karadeniz bölgesi ağızları arasında görülen ünlü yuvarlaklaşması benzerliği bu çalışmanın çıkış noktası olmuştur.

Eski Anadolu Türkçesinde belirli eklerde ve çok heceli bazı kelimelerde sistemli bir şekilde var olan yuvarlak ünlüler, bugün Doğu ve Kuzeydoğu Grubu ağızlarında olduğu gibi Batı Anadolu ağızlarının bir kısmında da bu özelliklerini sürdürmektedir. Kuzeydoğu ve Doğu Grubu ağızlarında hem düzleşme hem de yuvarlaklaşma sebebiyle dudak uyumsuzluğu meydana gelirken Batı Grubu ağızlarında düzlük-yuvarlaklık uyumu sadece yuvarlaklaşma ile bozulmaktadır. Bölgenin kuzeybatı, kuzey, kuzeydoğu ve doğusu ünlü yuvarlaklaşmasının yoğun olduğu alanlardır (Karahan, 1996: 124125). Batı Karadeniz bölgesi de Batı Grubu ağız bölgesi içinde yer almaktadır ve bölge ağzı ile Eski Anadolu Türkçesi dil özelliklerinden özellikle yuvarlaklaşma yönünden benzerlik göstermektedir. Leylâ Karahan, Eski Anadolu Türkçesinin kuruluşundaki yazı dili-ağız ilişkisini incelediği çalışmasında ünlü yuvarlaklaşması, ilerleyici benzeşme, ḩ ve damak n'si özelliklerinin hepsinin Orta 
Anadolu Bölgesi ve Orta ve Batı Karadeniz Bölgesi’nin Amasya, Tokat, Kastamonu, Bartın, Bolu, Zonguldak ile Ordu, Samsun, Sinop ve Giresun'un bazı köylerinin ağızlarında görüldügünü belirtmiştir (Karahan, 2006: 8-9). Batı Karadeniz Bölgesi ağzının Eski Anadolu Türkçesi ile ortaklaşan özellikleri bulunması, Eski Anadolu Türkçesinin kuruluşunda yazı dili-ağız ilişkisi yönünden değerlendirme yapma imkanı verecektir. Bölgede özellikle Bolu, Kastamonu ağızlarında hem kelime köklerinde hem de eklerde baskın şekilde ünlü yuvarlaklaşması görülmektedir. Batı Grubu ağızları içerisinde elbette ünlü yuvarlaklaşmasının olduğu farklı ağız alanları bulunmaktadır. $\mathrm{Bu}$ çalışmada yuvarlaklaşmanın yoğun şekilde görüldüğü bir coğrafya olarak Batı Karadeniz bölgesi belirlenmiş ve bu bölge ağızlarındaki ekler ünlü yuvarlaklaşması yönünden Eski Anadolu Türkçesi ile karşılaştırılmıştır.

\section{Ekler}

\section{Batı Karadeniz Ağızları İle Eski Anadolu Türkçesinde Sürekli Yuvarlak Ünlülü Ortak}

\section{1. İsimden İsim Yapım eki: $+l U$}

Eski Türkçeden beri işlek kullanılan eklerden biridir. Eski Türkçede ek $+l I g /+l U g$ şeklindeydi. Batı Türkçesine geçerken ekin bu asli şekli değișerek ek sonundaki g'ler düşmüştür. Bu düşme hadisesi ekin ünlüsüne de etki ederek düz ünlüleri de yuvarlaklaştırarak eki sadece yuvarlak ünlülü şekilde bırakmıştır (Ergin, 2012: 159-160). İsimlerden sıfat yapan ektir. Ünlüsü kurallı olarak yuvarlak ünlülüdür: adlu "adlı", boylu "boylu”, evlü “evli” (Gülsevin, 2017: 127).

Batı Karadeniz ağızlarında ise bu ek özellikle bazı yörelerde yoğun olarak yuvarlak ünlülü olarak kullanılmaktadır. Bolu ili ağızlarında ekin düz ünlülü şekilleri de olmasına rağmen yoğun olarak yuvarlak ünlülü kullanılmıştır: buralu, analu gızlu, çalılu, emeglü, çalgulu (Öztürk, 2019a: 69). Kastamonu yöresinde ise düz ünlülü tabanlara yaygın olarak yuvarlak ünlülü geldiği görülmüştür: maraklu, aslanlu, pasaklu, köylü, bilimli (Acar, 2012: 118). Düzce ili Kaynaşl1 ilçesi Yeniyurt ve Altınköy ağızlarında ise hem düz hem yuvarlak ünlülü kullanımları bulunmakta olup büyük oranda ek dudak uyumuna bağlanmıştır: emekli, kuyruklu, Kayaşlıya, Oflu, balluca (Gümüştel, 2019: 41-42). Zonguldak-Bartın-Karabük bölgesinde ise ek yazı dilindekine yakın bir kullanıma sahiptir. Uyum dışı olarak bazen yuvarlak ünlülü tabanlara düz ünlülü geldiği görülür: duzlı, köyli (Eren, 1997: 47). Zonguldak ağzında seyrek olarak düz ünlülü tabanlara yuvarlak ünlülü olarak geldiği görülmektedir: yaşluluk, evlülük (Çamurcu, 2011: 39). Yörenin doğu sınırı olan Sinop'un Ayancık ilçesi ağzında ise bu ek yaygın olarak yuvarlak ünlülüdür: tadlu, arzalu, emekli, sevdalula, salçalu (Gümüş, 2017: 57). Boyabat ilçesinde ise düz ünlülü tabanlarda yuvarlak kullanım görülmektedir: datlu, zelletlü (Akgül, 2019: 122).

Eski Anadolu Türkçesinde sürekli yuvarlak ünlülü kullanılan ekin, Batı Karadeniz bölgesinde yuvarlak ünlülü kullanımları bulunmaktadır. Bu kullanım Bolu, Kastamonu ve SinopAyancık ve Boyabat ağızlarında daha yoğun görülmektedir. Yuvarlak ünlülü kullanım bölgede en az Zonguldak-Bartın-Karabük ağzılarında görülmektedir.

\section{2. İsimden İsim Yapım Eki: $+s U z$}

$+s U z$ eki çok işlek bir yapım ekidir. Sahip olma, kendinde bulundurma görevindeki +1I/+1U ekinin karşıtıdır (Korkmaz, 2014: 140). Eski Anadolu Türkçesinde sürekli yuvarlak ünlülü olarak kullanılmıştır. Yokluk bildiren sıfatlar yapmaktadır: kardaşsuz "kardeşsiz", yagmursuz “yağmursuz", günahsuz "günahsız" (Gülsevin, 2017: 129).

Batı Karadeniz ağızlarında ise yuvarlak ünlülü olarak kullanıldığı görülmektedir. Yörenin bazı kesimlerinde yoğun şekilde yuvarlak ünlülü kullanılan ek, bazı kesimlerde ise kısmen de olsa düz ünlülü tabanlara yuvarlak ünlülü olarak gelmiştir. Bolu ili ağızlarında yaygın olarak yuvarlak ünlülü kullanılmaktadır: şekersüz, datlusuz, rahatsuz, gamsuz, terbüyesüz (Öztürk, 2019a: 70). Kastamonu ağzında ise düz ve yuvarlak ünlülü şekilleri kullanılmakta olup dudak uyumu dışında 
kullanımlar oldukça fazladır: sabansuz, akılsuz, yarsuz, anasuz, ipsiz, tahsilsiz (Acar, 2012: 118119). Düzce ili Kaynaşlı ilçesi Yeniyurt ve Altınköy ağızlarında ek dudak uyumuna bağlı olarak kullanılmaktadır: şerefsizlik, Dipsigolde (Gümüştel, 2019: 43). Zonguldak-Bartın-Karabük bölgesinde ise dudak uyumuna uygun kullanılmaktadır: yoksuzlukdan (Eren, 1997: 47). Zonguldak ağzında ise yuvarlak ünlülü kullanımı yaygındır: rahatsuz, uykusuz, haksuz, belirsüzü (Çamurcu, 2011: 39). Sinop'un Ayancık ilçesi ağzında baskın şekilde yuvarlak ünlülü kullanılmaktadır: malsuz, bakımsuzudu, ıssuz, etsüz (Gümüş, 2017: 57). Boyabat ilçesinde ise benzer şekilde daha çok yuvarlak ünlülü kullanılmaktadır: cembersüz, şeysüz (Akgül, 2019: 128).

Eski Anadolu Türkçesinde sürekli yuvarlak ünlülü kullanılan ek, Batı Karadeniz bölgesi ağızlarında da yuvarlak ünlülü karşımıza çıkmaktadır. Ekin Düzce, Bartın ve Karabük dışında kalan yerlerde yoğun şekilde yuvarlak ünlülü kullanıdığı görülmektedir.

\section{3. İlgi Hâli Eki: $+(n) U \tilde{n},+U m$}

Eski Anadolu Türkçesinde $+(n) U \tilde{n}$ şeklinde sürekli dar-yuvarlak ünlülü kullanılmıştır: Yaradılmaguñ evveli anlardur, oglanı iki talusınuñ arasında urup çakdı, ferişte taguñ kuvvetin ve kat1lıgın deñledi, benüm iş bunuñ gibi yalanum girçege geçürdiler (Gülsevin, 2017: 34-35).

Batı Karadeniz ağızlarında ek genellikle dudak uyumuna bağlı olarak kullanılmıştır. Bolu ili ağzında ilgi hâli eki ñ’li şekilde kullanılır. Ekin düz ve yuvarlak ünlülü şekilleri mevcuttur; ancak ek dudak uyumuna tam bağlı değildir: emmisünüñ, abinüñ, deyzenüñ, dayınıñ (Öztürk, 2019a: 73). Ek, 1. şahıs zamirlerine gelirken $+I m /+U m$ şeklindedir; ancak yuvarlak şekli yaygındır: benim gafam çallşmasa (Öztürk, 2019a: 153), benüm eviñ işini, bizüm burda hanay delle (Öztürk, 2019a: 73). Kastamonu ili ve yöresinde ilgi ekinin kullanımı Zonguldak-Bartın-Karabük illeri ağızlarıyla ortaktır. Ek, büyük oranda uyuma girmiştir: zahmetiñ, doñuzuñ, tüpüñ, masaniñ, ayunuñ, anamiy, bubamıy, amcasınıy, çarşunuy (Acar, 2012: 129). Zonguldak-Bartın-Karabük illeri ağızlarında ilgi hâli ekinin $+\mathrm{In} / \mathrm{Un},+\mathrm{nI} \tilde{\mathrm{n}} /+\mathrm{nU} \tilde{n},+\mathrm{Iy} /+\mathrm{Uy}$ ve $+\mathrm{nIy} /+\mathrm{nUy}$ şeklinde kullanımları vardır. Ek, bu yörede büyük oranda dudak uyumuna girmiştir: onnarın hızmatçıları, peygamberin gavli, köyin evleri, köyün evleri (Eren, 1997: 50). Düzce ili Kaynaşlı ilçesi Yeniyurt ve Altınköy ağızlarında ise Türkiye Türkçesi yazı dilindeki gibi kullanılmaktadır ve dudak uyumuna girmiştir: bunuñ, kızıñ, buranın, herkesin, ohulun (Gümüştel, 2019: 54-55). Zonguldak ağzında ise dudak uyumuna bağlıdır: onun suyuynan, devletin yaptuğu (Çamurcu, 2011: 42). Sinop Ayancık ilçesi ağzında ise ek büyük oranda dudak uyumuna bağlı kullanılmaktadır: sabrinin gelini, kızıñ biri, enişdemin damadı, çeşmenün yemeini (Gümüş, 2017: 61). Boyabat ilçesinde de dudak uyumuna bağlı olduğu görülmektedir: köyümüzün yöresi (Akgül, 2019: 132).

Eski Anadolu Türkçesinde sürekli yuvarlak ünlülü kullanılan ilgi eki, Batı Karadeniz bölgesi ağzılarında büyük oranda dudak uyumuna bağlanmıştır. Bölgede ilgi ekinin düz ünlülü tabanlara yuvarlak ünlülü şekilde gelmesi seyrek görülmektedir.

\section{4. İyelik Eki (1. ve 2. Teklik ile 1. ve 2. Çokluk Şahıslarda): $+\boldsymbol{U} m,+\boldsymbol{U} \tilde{n}+,+U m U z,+U \tilde{n} U z$}

Eski Anadolu Türkçesinde iyelik ekleri Türk dilinin diğer lehçelerindeki iyelik eklerinden farklı değildir. Ek, bu dönemin yaygın özelliği olarak dudak uyumunun dışında kalmıştır. Eski Anadolu Türkçesinde iyelik ekleri, dönemin genel yuvarlaklaşma eğilimi doğrultusunda 1 . ve 2 . şahıslarda yuvarlak ünlülü olarak karşımıza çıkar: ivüm, gücüm, ne māluñ var bañ virgil ḳamu, eyü adumuz, dükelüñüz, hemişe meclisünüz 'ālì olsun (Akar, 2018: 136).

Batı Karadeniz ağılarında ise iyelik ekinin 1. ve 2. şahıslarda düz ve yuvarlak ünlülü olarak kullanımları bulunmaktadır; ancak her iki şahısta da dudak uyumu dışında kalan yuvarlak ünlülü kullanımları görülmektedir. Bolu ili ağızlarında söz konusu iyelik eklerinin düz ünlülü tabanlara yuvarlak ünlülü olarak geldiği örnekler yaygındır: evüm, mayışım, yaşımuz, artanımuz, eviñizde, depeñize, avucuña, kendüñ (Öztürk, 2019a: 76-78). Söz konusu iyelik eklerinin birinci şahıslarda yuvarlak ünlülü kullanımı daha yaygın olduğu görülmektedir. Kastamonu ağzında ise ek yazı dilinde

Turkish Studies - Language, 15(1) 
olduğu gibidir: habarım, bubam, anañ, yüzün̈̈, yerimiz, suyumuzu, köyümüz, suyuñuzu, yoluñuzun (Acar, 2012: 139-140). Düzce ili Kaynaşlı ilçesi Yeniyurt ve Altınköy ağızlarında ise söz konusu şahıslar genellikle dudak uyumuna uymaktadır; ancak düz ünlülü tabanlarda yuvarlak ünlülü şekiller de bulunmaktadır: canum, başım, gücüm, yoluñ, geliñ̈̈ñ, olanumuz, cenazemiz (Gümüştel, 2019: 5052). Zonguldak-Bartın-Karabük illeri ağızlarında ise söz konusu şahıslarda iyelik eklerinin örnekleri şöyledir: adamım, gözüm, evin, lafiñ, hocamız, köyümüz, köyiñüz (Eren, 1997: 48-49). SinopAyancık ağzında bu ek büyük oranda dudak uyumuna bağlıdır: ġızım, evladım, eviñ, dayın,, insanımız, saygumuz, ġızıñızı (Gümüş, 2017: 64-65). Boyabat ağzında ise 1. ve 2. teklik ile 2. çokluk şahıs iyelik ekleri dudak uyumuna bağlıdır, 1. çokluk ekinde yuvarlak kullanımlar bazen bu uyumu bozmuştur: gelinim, annen, başımıza, yapanumuz, adamiñız (Akgül, 2019: 53).

İyelik eki Eski Anadolu Türkçesi döneminde yuvarlak ünlülü olarak birinci ve ikinci şahıslarda karşımıza çıkmaktadır. Batı Karadeniz bölgesinde Bolu ağzında söz konusu şahıslarda yuvarlak ünlülü kullanım yoğun görülmektedir. Düzce ile Kaynaşlı ilçesi Yeniyurt ve Altınköy ağızlarında ve Sinop-Boyabat ilçesinde nadiren yuvarlak ünlülü kullanım tespit edilmiştir.

\section{Görülen Geçmiş Zaman (1. ve 2. Teklik ile 1. ve 2. Çokluk Şahıs Çekimlerinde): - $d U m,-d U \tilde{n},-d U k,-d U \tilde{n} U z$}

Eski Anadolu Türkçesinde görülen geçmiş zaman eki 1. ve 2. şahıslarda $-d U m,-d U \tilde{n},-d U k$, -dUñUz şeklindedir: müslümānlar 'āşı ol oldum süci içdüm delü oldum, firişsteleri aña secde kıldurduñ, velikin biz on bāb eyledük, iy firişteler Muhammed ümmetini nice bulduñuz (Gülsevin, 2017: 96-97). Bu dönemde söz konusu şahıslarda sürekli düz ünlülü kullanılan ek bu sebeple dudak uyumu dışında kalmıştır.

Bat1 Karadeniz bölgesinde söz konusu ekin yuvarlaklaştığ1 görülür. Bolu ili ağızlarında 1. Çokluk şahısta bu durum sık görülür: bürlendim, yaşaduk, alduk, mafetdiñiz, uğraşduk (Öztürk, 2019a: 88-89). Kastamonu ağzında ekin 1. ve 2. tekil şahıs çekimlerinde yuvarlaklaşma pek görülmemektedir. Çokluk 1. şahıs çekimi bu ekin en sık yuvarlak ünlülü görüldüğü çekimdir: aldım, kestim, davrandl, çıkdık, yanduk, yapduk (Acar, 2012: 211-214). Düzce ili Kaynaşli ilçesi Yeniyurt ve Altınköy ağızlarında ise ek sadece çokluk 1. şahısta yuvarlaklaşarak uyum dışına çıkmıştır. Diğer şahıs çekimlerinde dudak uyumuna bağlıdır: aldım, sattım, çıktuk, enduk, yaptık (Gümüştel, 2019: 91). Zonguldak-Bartın-Karabük illeri ağızlarında ise ek çokluk birinci şahıs çekiminde sürekli yuvarlak ünlülüdür, diğer şahıslarda ise yuvarlak ünlülü kullanım olsa da ek genel olarak dudak uyumuna bağlanmıştır: yatdım, yatdıñ, getdim, getdiñ, yatduk, getdük, yatdıñı, gotdüñ, gelduñuz (Eren, 1997: 71-72). Sinop-Ayancık ağzında bu ek sadece çokluk 1. şahısta yuvarlak ünlülü olarak dudak uyumu dişında görülmektedir. Onun dışındaki şahıslarda dudak uyumuna bağlanmıştır: yetiştük, evlendük, bindük (Gümüş, 2017: 86). Boyabat ağzında da Ayancık ağzında olduğu gibi çokluk 1. şahıs çekiminde yuvarlak ünlülü kullanımlar görülmektedir: çalıştuk, ıslardug, geçüdük (Akgül, 2019: 67-68).

Görülen geçmiş zaman eki birinci ve ikinci şahıs çekimlerinde Eski Anadolu Türkçesinde sürekli yuvarlak ünlülü şekilde kullanılmaktaydı. Söz konusu ekler ilgili şahıslarda Batı Karadeniz bölgesinde de yuvarlak kullanımları görülmektedir. Ek genel olarak çokluk birinci şahısta yuvarlak ünlülü olarak kullanılmıştır. Diğer şahıslarda yuvarlak kullanım bulunmaktadır; ancak oldukça seyrektir.

\section{Geniş Zaman Eki: -Ur}

Geniş zaman her zaman için kullanılan bir ektir. Oluşu ve kılışı, konuşma anıyla, ondan önceki ve sonraki zamana taşıyabilir (Gülsevin, 2017: 100). Dar ünlüyle kurulan geniş zaman eki Eski Anadolu Türkçesinde daima yuvarlak ünlülüdür: gelür, utanuram, bilinür (Akca, 2016: 101). 
Batı Karadeniz bölgesinde ise ekin düz ünlülü tabanlarda yuvarlak ünlülü kullanıldığ1 örnekler görülmektedir. Bolu ili ağızlarında bunun örnekleri şu şekildedir: bilürüñ, pişirürlermişdi. Geniş zaman eki Bolu ağzında ekin bünyesindeki $r$ sesini kaybetmiştir, sadece ünlüsü ile kullanılmıştır. Bu tür kullanımlarda yuvarlak ünlü kullanıldığı görülmüştür: gelüledi (Öztürk, 2019a: 84). Kastamonu ağzında da geniş zaman ekinin kullanımı benzer şekildedir: alurun, giyerin, büşürsün, aluruz, inceldürüz (Acar, 2012: 202-210). Bolu ağzında görülen geniş zaman ekinin ünsüzünün düşmesi olayı Kastamonu ağzında da vardır: gelüsüñ, alusuñ, bilüsüñ̈̈z danışula (Acar, 2012: 204-210). Düzce ili Kaynaşlı ilçesi Yeniyurt ve Altınköy ağızlarında ise ekin düz ve yuvarlak ünlülü şekilleri bulunmakla birlikte düz ünlülü tabanlara yuvarlak ünlülü geldiği örnekler bulunmaktadır: bilür, getürür, yapar, oћunur (Gümüștel, 2019: 86-87). Zonguldak-Bartın-Karabük illeri ağızlarında geniş zaman eki $-A r,-I r, U r$ şeklindedir. Ancak 2. ve 3. şahıslarda $r$ ünsüzü genellikle düşmektedir (Eren, 1997: 68). Zonguldak-Bartın-Karabük yöresinde ekin düz ünlülü tabanlarda yuvarlak ünlülü kullanımı Bolu ve Düzce yöresine göre daha fazladır: alurum, gelür, bıraћur (Eren, 1997: 68). Ekin ünsüzünün düşmesi olayı Zonguldak-Bartın-Karabük yöresinde de görülür: alu "alır”, gelüle "gelirler”, kesilü "kesilir" (Eren, 1997: 68). Sinop-Ayancık ilçesi ağzında ekin bazı örneklerde düz ünlülü tabanlara yuvarlak ünlülü olarak geldiği görülür: gelürüm, giderin. Ayancık ilçesinde $r$ ünsüzünün düştüğü geniş zaman eki kullanımları şöyledir: alusun "alırsın", bandurusun "bandırırsın", alu "alır", yapılu "yapılır" (Gümüş, 2017: 83-84). Boyabat ilçesi ağzında ise düz ünlülü tabanlarda yuvarlak ünlülü örnekleri bulunmaktadır: bilürün, gelüsüñ, bilüsüñ (Akgül, 2019: 74-75)

Eski Anadolu Türkçesinde dar ünlülü bir fiile geniş zaman eki sürekli yuvarlak ünlülü gelmiştir. Batı Karadeniz bölgesinde de bu şekilde yuvarlak ünlülü şekiller yaygın olarak bulunmaktadır. Özellikle Zonguldak-Bartın-Karabük yöresi ile Bolu ve Kastamonu yöresinde oldukça yaygındır.

\section{Emir Kipi}

$\mathrm{Bu}$ ek Eski Anadolu Türkçesi metinlerinde birinci ve ikinci şahıslarda istek, üçüncü şahıslarda emir görevini üstlenmektedir (Akar, 2018: 181). Bu kip ekinin Eski Anadolu Türkçesinde üçüncü teklik ve bütün çokluk şahıslarda çekimi sürekli yuvarlak ünlü ile yapılmaktadır: 'aşķıla bog̉duñ cānum al öleyüm, Tañrı bizi yurdumuzdan ırmasun, varalum düşmeni ḥaķlayalum didi, Dirse han varuñ getürüñ öldüreyim didi, ḳız1l atlas döşsesünler (Akar, 2018: 181-182).

Batı Karadeniz bölgesinde ek bazı ağız bölgelerinde dudak uyumunun dişında yuvarlak ünlülü olarak kullanılmıştır. Bolu ili ağızlarında ek dudak uyumuna bağlı durumdadır: söyleyeyin "söyleyeyim", bakalım, esirgesin, eletelim (Öztürk, 2019a: 91). Kastamonu ağzında büyük oranda dudak uyumuna bağlıdır; ancak birkaç örnekte düz ünlülü tabanlara yuvarlak ünlülü geldiği görülmüştür: yatuñ "yatırın”, basalım, sarılalım (Acar, 2012: 232-233). Düzce ili Kaynaşlı ilçesi Yeniyurt ve Altınköy ağızlarında ise teklik üçüncü şahısta çok az örnekte yuvarlak şekli bulunmaktadır: virsüñ (Gümüştel, 2019: 95). Zonguldak-Bartın-Karabük illeri ağızlarında bu ek dudak uyumuna bağlamıştır. Çok az örnekte dudak uyumu dışında yuvarlak ünlülü kullanım bulunmaktadır: verelüm (Eren, 1997: 75). Sinop-Ayancık ağzında ek dudak uyumuna bağlıdır: görelim, alıyın, söyleyiñ (Gümüş, 2017: 90-91). Boyabat ilçesi ağzında yuvarlak ünlülü olarak uyum dışı kullanıldığı örnekler bulunmaktadır. Uyum dışı yuvarlak ünlülü kullanımlar teklik üçüncü şahıs çekiminde görülmektedir: gelsüñ, vesün, katarsıñ, gouşalım (Akgül, 2019: 83).

Eski Anadolu Türkçesinde söz konusu şahıslarda yuvarlak ünlülü kullanılan bu ekin, Batı Karadeniz bölgesi ağızlarında yuvarlak ünlülü şekilleri nadiren bulunmaktadır. Kastamonu, Düzce, ve Sinop-Boyabat ilçesi ağzında dudak uyumu dışında yuvarlak ünlülü kullanımları bulunmaktadır. $\mathrm{Bu}$ ağız bölgelerinin dışında ek dudak uyumuna bağlanmış durumdadır. 


\section{8. İsimden İsim Yapım Eki: $+c U k$}

Türkçenin küçültme, acıma ve pekiştirme bildiren eklerinden biridir. Eski Anadolu Türkçesinde sürekli yuvarlak ünlülü kullanılmaktadır: aglancukları, azacuk, nesnecükleri (Akar, 2018: 128-129).

Batı Karadeniz bölgesinin bütün ağızlarında bu ekin yuvarlak şekli bulunmaktadır. Bolu ili ağzında ek genellikle yuvarlak ünlülü kullanılır: azcuk, sıcacuk, ufacuk, incecik (Öztürk, 2019a: 70). Kastamonu ağzında da ek baskın șekilde yuvarlak ünlülü kullanılmaktadır: yumşacuk, havacuk, yakıncuk, depecük (Acar, 2012: 120). Düzce ili Kaynaşlı ilçesi Yeniyurt ve Altınköy ağızlarında genel olarak yuvarlak ünlülü kullanılır: yancuğa, kadarcuḩ (Gümüştel, 2019: 43-44). Bartın ve yöresi ağızlarında bu ek genellikle yuvarlak ünlülü kullanılmaktadır: bidanecük, kimsecükle, eçcük "azıcık", şıpdacuk "çabucak" (Korkmaz, 1994: 23). Sinop-Ayancık ilçesi ağzında bölgenin genelinde olduğu gibi baskın şekilde yuvarlak ünlülü kullanılmıştır: tanecük, biricük, kerecük, güçcükleri (Gümüş, 2017: 57). Boyabat ilçesi ağzında ise yuvarlak ünlülü şekilleri yaygındır: milyoncuk, biricük, alçacukgine (Akgül, 2019: 141, 162, 217).

Eski Anadolu Türkçesinde sürekli yuvarlak ünlülü kullanılan bu ek, Batı Karadeniz bölgesi ağzılarında ise baskın şekilde yuvarlak ünlülü kullanılmıştır. Ekin dudak uyumuna bağlı kullanımları çok az bulunmaktadır.

\section{Fiilden İsim Yapım Eki: - $g U$}

Eski Türkçeden beri işlek bir ektir. Eski Anadolu Türkçesi metinlerinde çeşitli soyut isimler ve araç-gereç isimleri yapmaktadır (Akar, 2018: 133). Bu dönemde sürekli yuvarlak ünlülü kullanılmaktadır: sevgü, yiygü “yiyecek”, çalku “çalgı" (Akar, 2018: 133).

Ek, Batı Karadeniz bölgesinde yuvarlak ünlülü kullanımlara sahiptir. Bolu ili ağzında büyük oranda yuvarlak ünlülü kullanılmıştır: çalgu, çalgulu, süzgü (Öztürk, 2019a: 71). Kastamonu ağzında ise bu ek baskın şekilde yuvarlak ünlülü kullanılmaktadır: çalgu, içgüler, sergü, bilgü, yaygu, alguyu (Acar, 2012: 126). Zonguldak-Bartın-Karabük illeri ağızlarında yuvarlak ünlülü kullanımları yaygındır: çalgu (Eren, 1997: 183), işgü "içki” (Eren, 1997: 188). Sinop-Ayancık ilçesi ağzında ise ekin yuvarlak ünlülü kullanımları bulunmaktadır: çizgü, sevgü, saygımız, sevgimizi (Gümüş, 2017: 59). Boyabat ilçesi ağzında ise ekin düz ünlülü tabanlara yuvarlak ünlülü geldiği kullanımlar görülmektedir: sorguya, görgü, sargulu, saygulularıdı (Akgül, 2019: 139, 175, 181, 193).

Eski Anadolu Türkçesinde sürekli yuvarlak ünlülü kullanılan bu ek, Batı Karadeniz bölgesi ağzılarında genel olarak yuvarlak ünlülü kullanılmıştır. Bunun dışında ekin dudak uyumuna bağlı kullanımları da bulunmaktadır.

\section{0. Çokluk 1. Şahıs Eki: $-U z$}

Çokluk birinci şahıs eki, Eski Anadolu Türkçesinde sürekli yuvarlak ünlülüdür: seviye şöyle virmişüz, geçen gice cāndan ırup şöyle gitmişüz, gözümüz göre helāk olısaruz diyü ag̉laşdılar (Akar, 2018: 167).

Batı Karadeniz bölgesinde ekin kullanımında yuvarlaklık görülür. Bolu ili ağızlarında yuvarlak kullanım yaygındır: yapmayoz, gelmüşüz, indiremiyüz, içerüs, yirüz (Öztürk, 2019a: 94). Kastamonu ağzında ise geniş zaman ve öğrenilen geçmiş zaman çekiminde genellikle yuvarlak ünlülü olduğu görülür: yaparuz, çıkaruz, basaruz (Acar, 2012: 207), vermişüyüz (Acar, 2012: 217). Düzce ili Kaynaşlı ilçesi Yeniyurt ve Altınköy ağızlarında ise bu şahıs eki dudak uyumuna bağlı olarak tespit edilmiştir: ederiz, yetişiriz, yaparı (Gümüştel, 2019: 80). Zonguldak-Bartın-Karabük illeri ağızlarında yuvarlak ünlülü kullanımı bulunmaktadır: banaruz, yakmışuz, vemişüz, yaparız (Eren, 1997: 63). Sinop-Ayancık ilçesi ağzında da düz ünlülü tabanlara yuvarlak ünlülü geldiği 
görülmektedir: goşaruz, derüz, giderüz, bişiririz (Gümüş, 2017: 84). Boyabat ilçesi ağzında ise ayn1 durum görülür: slkaruz, ataruz, guyaruz (Akgül, 2019: 118, 121).

Çokluk birinci şahıs ekinin Batı Karadeniz bölgesinde Eski Anadolu Türkçesindeki gibi yuvarlak ünlülü kullanımları bulunmaktadır. Bu kullanım Eski Anadolu Türkçesindeki gibi sürekli yuvarlak ünlülü değildir. Bu yuvarlak kullanım bölgenin her ağız bölgesinde belirli oranda görülmektedir. Ekin dudak uyumuna bağlı kullanımları da bulunmaktadır.

\section{Zarf-fiil Eki: $-U p$}

Eski Türkçede - $p$ olarak kullanılan eke daha sonra yanındaki yardımcı ünlü eklenmiş ve p'nin yuvarlaştırma etkisiyle - Up biçimini almıştır: döymeyüp cān virdiler anlar tamām, yapışup çıardular, ol gönlegi iltüp ya' kuba vire (Akar, 2018: 200). Eski Anadolu Türkçesinde sürekli yuvarlak ünlülü kullanılan eklerden biri olup yaygın bir zarf-fiil ekidir.

Batı Karadeniz bölgesi ağızlarında bu ekin yuvarlak ünlülü kullanımı yaygındır. Bolu ili ağzında bu zarf-fiil eki baskın şekilde yuvarlak ünlülü kullanılmaktadır: uyuyup, kesilüp, doyurub (Ö̈ztürk, 2019a: 100). Kastamonu ağzında ekin yuvarlak kullanımı Bolu ağzı kadar yaygın değildir. Örneklerde büyük oranda dudak uyumuna girdiği görülür; ancak yuvarlak ünlülü uyum diş1 kullanımları yine de vardır: birleşib, gelib, goyup, büşürüp, satıp, garşulaşup (Acar, 2012: 274). Düzce ili Kaynaşlı ilçesi Yeniyurt ve Altınköy ağızlarında ise dudak uyumuna bağlı kullanılmaktadır: gidip, biçip, çevirip, doğup (Gümüştel, 2019: 103). Zonguldak-Bartın-Karabük illeri ağızlarında ise belirli oranda dudak uyumuna giren ekin düz ünlülü tabanlara yuvarlak ünlülü geldiği kullanımlar da bulunmaktadır: verib, sorub, sevüb, furub "vurup", düşünüb (Eren, 1997: 89). Sinop-Ayancık ilçesi ağzında bu ek genellikle dudak uyumuna bağlı kullanılsa da uyum dışı yuvarlak ünlülü kullanımları bulunmaktadır: yapıp, çalışıp, bilip, girüp, gidip (Gümüş, 2017: 104). Boyabat ilçesi ağzında ise dudak uyumu dışı yuvarlak kullanımlar mevcuttur: dutup, gelüp, götürüp, bişürüp (Akgül, 2019: 149, 196, 218, 240).

Eski Anadolu Türkçesinde sürekli yuvarlak ünlülü kullanılan ek, Batı Karadeniz bölgesi ağızlarında belirli oranda dudak uyumu dışında yuvarlak ünlülü kullanılmıştır. Bu anlamda Bolu ağZı bu ekin en yaygın şekilde yuvarlak ünlülü kullanıldığı ağız bölgesidir. Bölgenin diğer yörelerinde ekin yuvarlak ünlülü uyum dışı kullanımı az görülmektedir.

\section{Sifat-fiil Eki: $-d U k$}

Köktürk metinlerinden beri rastlanan bir sıfat-fiil ekidir. Oğuz ağızlarına ait bir ek olduğu sanılmaktadır. Diğer sıfat-fiil eklerinden ayrılan özelliği çekim ekleri alabilmesidir: gitdügi yolca gelürdi ol dede, söz sıduġını unıdur ol dem, emek yidügümüzi çün bileler (Akar, 2018: 191). Eski Anadolu Türkçesinde sürekli yuvarlak ünlülü kullanılmıştır.

Batı Karadeniz bölgesinde bu ekin yuvarlak ünlülü kullanımı görülmektedir. Bolu ili ağzında bu kullanım yaygındır: beledüğ̈̈m "belediğim", doladuğum "doladığım", diledüğüm "dilediğim" (Öztürk, 2019a: 119). Kastamonu ağzında ise baskın şekilde yuvarlak ünlülüdür: yapdudukları "yaptırdıkları", sardukları "sardıkları", vedükleri "verdikleri” (Acar, 2012: 269-270). Düzce ili Kaynaşlı ilçesi Yeniyurt ve Altınköy ağızlarında dudak uyumuna genel olarak bağlanmıştır: çalıştı̆̆g, geldikten, olduğu (Gümüştel, 2019: 104). Zonguldak-Bartın-Karabük illeri ağızlarında ek yuvarlak ünlülü kullanıldığı ve dudak uyumu dışında kaldığı örnekler bulunmaktadır. Ek bu bölgede birtakım fonetik değişiklikler göstermiştir: galkdı_1 "kalktığı", atduceumuz "atdığımı", geldü "geldiğgi”, veduceu "verdiği" (Eren, 1997: 88). Sinop-Ayancık ilçesinde de ek genellikle yuvarlak ünlülü kullanılmıştır: görmedüüm "görmediğim”, görüün "gördügün” (Gümüş, 2017: 104). Boyabat ilçesi ağzında ise ekin yuvarlak kullanımı sık görülmektedir: noldugunu "ne olduğunu", endüğ̈̈ "indiği”, türedü̆̈̈̈ “türediği”, verdiği, yakıldiğg (Akgül, 2019: 155, 224, 251, 255, 257). 
Eski Anadolu Türkçesinde sürekli yuvarlak ünlülü kullanılan ekin bölgede hemen hemen her ağız bölgesinde yuvarlak ünlülü kullanımı görülmektedir. Bölgede Düzce dışındaki ağız bölgelerinde ek yaygın şekilde yuvarlak ünlülü kullanılmaktadır.

\section{Fiilden Fiil Yapım Eki: - $U \boldsymbol{r}$ -}

Geçişsiz fiillerden geçişli çatılı fiiller yapan yaygın bir ektir. Eski Anadolu Türkçesi metinlerinde yuvarlak ünlülü olarak görülür: kaçurdılar, içürdiler, bişürdi, țoyurdum, yitürdi (Akar, 2018: 162). Ekin imlası son zamanlara kadar değişmeden devam etmiştir (Timurtaş, 2012: 117).

Batı Karadeniz bölgesi ağızlarında söz konusu ekin yuvarlak kullanımı seyrektir. Bolu ili ağzında yuvarlak ünlülü kullanımları nadiren bulunmaktadır: geçüreceñ (Öztürk, 2019a: 154). Kastamonu ağzında da seyrek şekilde yuvarlak ünlülü kullanım bulunmaktadır: yaturuya, içirüye "içiriyor" (Acar, 2012: 186). Düzce ili Kaynaşıı ilçesi Yeniyurt ve Altınköy ağızlarında dudak uyumuna bağlıdır: doyuramadı, çıћardın (Gümüştel, 2019: 76). Sinop-Ayancık ilçesi ağzında bu ekin yuvarlak kullanımı görülmektedir: bişüriyoñ, doyuruyon, düşüremediñ (Gümüş, 2017: 79). Boyabat ilçesi ağzında ise yuvarlak kullanımı bölgenin geneline göre daha fazladır: doyurudum, doğurdu, getürüyo, giyürdüle (Akgül, 2019: 112, 114, 125, 127).

Eski Anadolu Türkçesinde genel olarak yuvarlak ünlülü kullanılan -Ur-fiilden fiil yapım ekinin, Batı Karadeniz bölgesi ağzılarında da yuvarlak ünlülü kullanımları nadiren bulunmaktadır. Bolu, Kastamonu, Sinop-Ayancık ilçesi ağızlarında seyrek olarak yuvarlak ünlülü görülen ek, SinopBoyabat ilçesinde bölgenin geneline göre daha yaygın görülmektedir.

\section{Fiilden Fiil Yapım Eki: -dUr-}

Eski Anadolu Türkçesinde en yaygın görülen ettirgenlik eklerindendir. Geçişli ve geçişsiz fiillerden geçişli fiiller yapar. Ekin ünlüsü bu dönemde sürekli yuvarlaktır: otaḳ dikdürdi "diktirdi”, kaldurub "kaldırıp", at çapdurdı "koşturdu", bildürdi "bildirdi" (Akar, 2018: 160).

Batı Karadeniz bölgesinde ekin yuvarlak ünlülü kullanımı yaygındır. Bolu ili ağzında $-d U r$ eki yaygın şekilde yuvarlak ünlülü kullanılmaktadır: bañduracāñ, yandurma, bozduramam, bagdurlyolla (Öztürk, 2019a: 82). Kastamonu ağzında sürekli yuvarlak ünlülü kullanılmaktadır: yidürecesiñ "yedireceksin", gezdürüle "gezdirirler", tütdürüyon "tüttürüyorsun”, yazdurmuş "yazdırmış" (Acar, 2012: 187). Ek, Kastamonu bölgesinde - $\dot{g} U r$ şeklinde de görülmektedir. Bu şekilde de sürekli yuvarlak ünlülüdür: ergürüse "erdirirlerse", durgurlarıdı "durdururlardı", durguruviymişle "durduruvermişler" (Acar, 2012: 187). Zonguldak-Bartın-Karabük illeri ağızlarında yuvarlak ünlülü şekilleri bulunmaktadır. Ekin bu bölgede fonetik yönden farklı şekilleri bulunmaktadır: duradursuñ, yapdūsuñ "yaptırsın", yapdīsınlā "yaptırsınlar" (Eren, 1997: 67). SinopAyancık ilçesi ağzında ise sürekli yuvarlak ünlülü kullanılmıştır: galdurup "kaldırıp", indürün "indirin”, gezdürü "gezdirir”, söyletdürceñ "söyletdireceksin” (Gümüş, 2017: 79). Boyabat ilçesinde ise ekin yuvarlak ünlülü kullanımı yaygındır: bindürüleridi "bindirirlerdi", çalduran "çaldıran", gezdürüyola "gezdiriyorlar" (Akgül, 2019: 109, 111, 117).

Eski Anadolu Türkçesinde sürekli yuvarlak ünlülü kullanılan ek, Batı Karadeniz bölgesi ağzılarında da yoğun şekilde yuvarlak ünlülü kullanılmaktadır. Özellikle Bolu, Kastamonu ve Sinop bölgesinde yuvarlak kullanım yaygındır. Bölgede sadece Düzce bölgesinde ek dudak uyumuna büyük oranda bağlı kullanılmaktadır.

\section{Bildirme Eki (3. Teklik ve 3. Çokluk Şahıslarda): $+d U r(l A r)$}

Eski Anadolu Türkçesinde dudak uyumu dışında kalan eklerden biridir. Sürekli yuvarlak ünlülü şekilde kullanılmıştır: bir ḩoş makāmdur, cihān ḳaç ḳısımdur ve cihānı yaradan ḳaçdur, aña kuldur bu cümle çarh u felek, hisse almaḳdur bu sözlerden iyār, girü ol dāyim olanduryaradan (Akar, 2018: 183). 
Batı Karadeniz bölgesi ağızlarında yuvarlak ünlülü şekilleri görülmektedir. Bolu ili ağzında genel olarak yuvarlak ünlülü kullanılmıştır: yanyandadur, vardur, senedür, armutdur, cevizdir, senedir. Ekin son sesinin düştüğü şekilleri de bulunmaktadır. Bu örneklerde ekin ünlüsü sürekli yuvarlak ünlülüdür: gibidü "gibidir", betonarmedü "betonarmedir", birincidü "birincidir", güzeldü "güzeldir" (Öztürk, 2019a: 80). Kastamonu ağzında ek son ünsüzü düşmüş şekilde ve genellikle yuvarlak ünlülü kullanılmıştır: yaķındu "yakındır", yok,dur "yoktur", deründü "derindir" (Acar, 2012: 263). Düzce ili Kaynaşlı ilçesi Yeniyurt ve Altınköy ağızlarında ise düz ünlülü tabanlarda yuvarlak kullanımlar bulunmaktadır: yoћtur, ikidedir, vardur (Gümüştel, 2019: 101). ZonguldakBartın-Karabük illeri ağızlarında ek dudak uyumuna bağlı kullanılmaktadır: nedir, bandurmadır, $v \bar{a} d \imath r, y o \hbar d u r$ (Eren, 1997: 86). Sinop-Ayancık ilçesi ağzında ise dudak uyumuna bağlı kullanıldığı görülmektedir: mumdur, işdir (Gümüş, 2017: 101). Boyabat ilçesi ağzında da ek dudak uyumuna bağlıdır: vardır, böyledir, ġaçdır (Akgül, 2019: 220, 240, 268).

Eski Anandolu Türkçesinde sürekli yuvarlak ünlülü kullanılan ek, Batı Karadeniz bölgesinde Bolu ve Kastamonu ağızlarında genellikle yuvarlak ünlülü kullanılmıştır. Düzce bölgesinde de kısmen yuvarlak ünlülü kullanımlar bulunmaktadır. Zonguldak, Bartın ve Karabük ağızları ile Sinop Ayancık ve Boyabat ağızlarında dudak uyumuna bağlanmış durumdadır.

\section{Gereklilik Kipi: $-m A l U$}

Eski Anadolu Türkçesinde gereklilik kip eki olarak -mak gerek, -ma gerek, -sa gerek, -a gerek şekilleriyle sağlanmıştır. Bugün kullanılan -mAlI şekli Eski Anadolu Türkçesi döneminde birkaç örnek dışında henüz yaygınlaşmamıştır ve bu dönemde - $m A l U$ şeklinde kullanılmıştır: eger hod bilmelü olaydı ol rāz, ne yarar ki istemelü olalar (Akar, 2018: 178-179).

Bolu ili ağzında gereklilik kipinin müstakil eki yoktur. Başka kip ekleri ile gereklilik anlamı sağlanmaktadır. Yazı dilindeki -mAlI eki günlük konuşmalarda yer almaz (Öztürk, 2019a: 93). Kastamonu ağzında bu ek üçüncü şahıs çekimlerinde görülmektedir ve bu çekimlerde yuvarlak ünlülü kullanım görülmektedir: ġonuşmalu "konuşmalı", ekmelü "ekmeli", çekmelü "çekmeli", olmalulā "olmalılar" (Acar, 2012: 228-229). Zonguldak-Bartın-Karabük illeri ağızlarında ek dudak uyumuna bağlı durumdadır. Bilmelịm, görmelisiñ, yemelisiñiz (Eren, 1997: 77). Sinop-Ayanc1k ilçesi ağzında gereklilik eki olarak -mak lazım yapısı ile - $m A l U$ şekli kullanılmaktadır. $-m A l U$ şekli ise yuvarlak ünlülü kullanılmıştır: gorksmaluymuş (Gümüş, 2017: 91-92), dinlenmelü (Gümüş, 2017: 162). Boyabat ilçesi ağzında ise ek dudak uyumuna bağlı olarak kullanılmıştır: yimeliymiş, sormall, yapmalı (Akgül, 2019: 108, 261, 270).

Söz konusu ek Eski Anadolu Türkçesinde yuvarlak ünlülü olarak kullanılmıştır. Batı Karadeniz bölgesi içerisinde ise Kastamonu ve Sinop bölgesinde yuvarlak ünlülü ve dudak uyumu dışında kullanıldığı görülmüş̧ür.

\section{Batı Karadeniz Ağızlarında Sonradan Yuvarlaklaşan Ekler}

\section{1. İsimden İsim Yapım Eki: $+l I k$}

Eski Türkçeden bu yana yaygın şekilde kullanılan ve isimlerden soyut adlar, yer adları, bağl1lık adları yapan ektir: artukluk "fazlalık", iylükleri, ergilik "yanlışlık", delülige, yoldaşlığa (Akar, 2018: 130).

+lIk eki Batı Karadeniz ağılarında ise düz ünlülü kullanımları bulunmakla beraber genellikle yuvarlak ünlülüdür. Bolu, ekin baskın olarak yuvarlak ünlülü olarak kullanıldığı ağız bölgesidir: çobanluk, bakmamazluk, temüzlük, sapukluk (Öztürk, 2019a: 70). Kastamonu ağzında eki düz ve yuvarlak kullanımları bulunmaktadır. Ancak yuvarlak ünlülü uyum dışı kalan örnekleri de görülmektedir: yıllukdur, ġaranluk,da, maşaluk, sarlluk (Acar, 2012: 117). Düzce ili Kaynaşlı ilçesi Yeniyurt ve Altınköy ağızlarında ise ek büyük oranda dudak uyumuna bağlanmıştır: rahatlık, günlük, uşahluflarıla (Gümüştel, 2019: 40-41). Zonguldak-Bartın-Karabük illeri ağızlarında ise ek yine 
büyük oranda dudak uyumuna bağlı kullanılmaktadır: aşlıћdan, esgellik, ağllluk (Eren, 1997: 47). Zonguldak ağzında da nadiren düz ünlülü tabanlara yuvarlak ünlülü olarak geldiği görülmektedir: birlük (Çamurcu, 2011: 38). Sinop-Ayancık ağzında ek genel olarak dudak uyumuna bağlıdır. Ancak çok az örnekte yuvarlak ünlülü kullanımları bulunmaktadır: evladluk, çocukluk, senelik, aylık (Gümüş, 2017: 56). Boyabat ilçesi ağzında da Aybastı ağzına benzer şekilde kullanılmıştır: samanluklara, hastaluk, demircilük (Akgül, 2019: 148, 150, 169).

Eski Türkçede dört şekilli de kullanılan ek, Eski Anadolu Türkçesinde genellikle düz ünlülü kullanılmıştır. Bölge ağzında ise ekin yuvarlak ünlülü kullanımları görülmektedir. Özellikle Bolu, Kastamonu ve Sinop-Boyabat ilçesi ağızlarında ekin düz ünlülü tabanlara yuvarlak ünlülü geldiği kullanımlar yoğun şekilde görülmektedir.

\section{2. Öğrenilen Geçmiş Zaman Eki: -mIş}

Geçmişte gerçekleşen bir oluş ya da kılışın bizzat görülmediği, başkası tarafindan nakledildiği durumlarda bu zaman kullanılır. Sürekli düz-dar ünlü ile kulanılır: niçe yıldur ki şol çopanuñ ardına düşmişsin anuñ sürüsin güdersin ve uyku dadın bulmazsın yidügüñ yirine siñmez dostlardan ayru bir pāre arpa etmegine ki çopandan artar kana' āt itmişsin (Gülsevin, 2017: 88).

Batı Karadeniz bölgesinde bu ekin yuvarlak ünlülü kullanımları görülmektedir. Bolu ili ağzında genellikle dudak uyumuna bağlı olan ek, nadiren uyum dışına çıkılarak yuvarlak ünlülü kullanılmıştır: gelmüşüz, almamışsıñız, yapmış (Öztürk, 2019a: 90). Kastamonu ağzında genellikle dudak uyumuna bağlı kullanılmıştır; ancak çokluk birinci şahısta az sayıda örnekte yuvarlak kullanımlarına rastlanmıştır: ġalmuşuyuz, almuşuz, vamuşuz (Acar, 2012: 217-218). Düzce ili Kaynaşlı ilçesi Yeniyurt ve Altınköy ağızlarında dudak uyumuna bağlı durumdadır: toplamışlar, sökmüş, kırılmış, kurdurmuş, verilmiş (Gümüştel, 2019: 93). Zonguldak-Bartın-Karabük illeri ağızlarında da ek dudak uyumuna bağlıdır: ölmüşük, vemişsüyüz, yemişük, dökülmüş (Eren, 1997: 73). Sinop-Ayancık ağzında dudak uyumuna bağlıdır: olmuşuñ, atmış, delmiş, görmüş, yazmışla (Gümüş, 2017: 87-88). Boyabat ağzında da büyük oranda dudak uyumuna bağlı olan ek, bir örnekte uyum dış1 şekilde yuvarlak ünlülü görülmüştür: ġaldımuşun "kaldırmışsın" (Akgül, 2019: 70).

-mIŞ öğrenilen geçmiş zaman eki, Eski Anadolu Türkçesinde sürekli düz ünlülü kullanılan bir ektir. Batı Karadeniz bölgesinde ise ek büyük oranda dudak uyumuna bağlanmış durumdadır. Sadece Bolu ve Kastamonu ağızlarında nadiren yuvarlak ünlülü kullanımlarına rastlanmıştır.

\section{Fiilden Fiil Yapım Eki: -(I)n-}

Eski Türkçeden bu yana bir değişikliğe uğramamıştır. Ekin yardımcı ünlüsü Eski Anadolu Türkçesinde düz şekilde olup uyum dışıdır. Eski Anadolu Türkçesinden sonra bu yardımcı sesler tekrar ünlü uyumuna girmiştir (Yelten, 2009: 258). Ekin ünlüsünde yuvarlaklaşma seyrek olarak görülür: olun-, okun- (Gülsevin, 2017: 154).

Batı Karadeniz bölgesinin bazı ağız bölgelerinde bu ekin yuvarlak ünlülü şekli bulunmaktadır. Kastamonu ağzında ekin dudak uyumuna aykırı kullanılmış yuvarlak ünlülü şekli bir örnekte tespit edilebilmiştir: sevünü "sevinir" (Acar, 2012: 207). Bölgede ayrıca Sinop-Ayancık ilçesi ağzında yuvarlak ünlülü kullanım tespit edilmiştir: sevünüdük "sevinirdik" (Gümüş, 2017: 207).

Eski Anadolu Türkçesinde genellikle düz ünlülü kullanılan ek, Batı Karadeniz bölgesinin bazı ağızlarında az sayıda örnekte yuvarlak ünlülü tespit edilmiştir.

\section{Fiilden Fiil Yapım Eki: -(I)ş-}

İşteş çatılı fiiller yapmak üzere kullanılan bir ektir. Bir işin karşılıklı ya da birlikte yapıldığını belirtir (Akar, 2018: 161). İşteşlik eki -(I)ş, Eski Anadolu Türkçesinde genellikle düz ünlülü 
kullanılmıştır: irişdüm “eriştim”, görişür "görüşür”, urışuban "savaşarak”, sürtişür "sürtüşür" (Akca, 2016: 105).

Batı Karadeniz bölgesinde bu ekin yuvarlak ünlülü kullanımı oldukça seyrektir. Kastamonu ağzında sadece şu örnekte tespit edilmiştir: yetüşdüdü "yetiştirdi” (Acar, 2012: 383). Sinop-Ayanc1k ilçesi ağz1 yetüştüdüm "yetiştirdim" (Gümüş, 2017: 153), Boyabat ilçesi ağzında yetüşemedim (Akgül, 2019: 251) örneklerinde söz konusu ekin yuvarlak ünlülü şekilleri tespit edilmiştir.

İşteşlik eki -(I)ş, bölgede yuvarlak ünlülü ve dudak uyumuna aykırı olarak Kastamonu ve Sinop yöresinde tespit edilmiştir. Bölgenin kalan kısmında ek dudak uyumuna tam bağlanmış durumdadir.

\section{Belirtme Hâl Eki: $+I$}

Belirtme eki, ünsüzle biten isimlere $+I$, ünlü ile biten isimlere $+(y) I$ şeklinde eklenir. $\mathrm{Bu}$ şeklin Eski Türkçedeki isimlere gelen $+(I) g$ ekinin devamı olduğu genel bir düşüncedir. Eski Türkçedeki bu ekin g ve g sesleri Eski Anadolu Türkçesi döneminde düşünce baağlama ünlüsü ekin görevini üzerine almış ve ek sürekli düz-dar şeklinde kullanılmıştır: göñlümi, savaşı, odı, ķulı (Yelten, 2009: 289-290).

Batı Karadeniz bölgesinde bu ekin yuvarlak ünlülü kullanımı görülmektedir. Bolu ili ağızlarında ekin özellikle düz ünlülü tabanlara yuvarlak şekilde geldiği kullanımlar bulunmaktadır: yerü, hocalığu, otlaklaru, türbelerü (Öztürk, 2019a: 73). Kastamonu ağzında ise dudak uyumuna bağlı olarak kullanılmıştır: baççemi, başımı, yolumuzu, tohumunu (Acar, 2012: 131). Düzce ili Kaynaşlı ilçesi Yeniyurt ve Altınköy ağızlarında düz ünlülü tabanlarda yuvarlak ünlülü kullanım tespit edilmemiştir. Tam tersine yuvarlak tabanlara düz ünlülü eklendiği örnekler bulunmaktadır: onu, onı, bunı, bunnarı, arazisini (Gümüştel, 2019: 56-57). Zonguldak-Bartın-Karabük illeri ağızlarında da ek genellikle dudak uyumuna bağlıdır. Uyumsuzluk bazen yuvarlak tabanlara düz ünlülü gelmesi sebebiyle gerçekleşmiştir: suyi "suyu”, düvüni "düğünü”, midesini, bunu, çocuvu "çocuğu" (Eren, 1997: 51). Sinop-Ayancık ağzında ise ek dudak uyumuna bağlı durumdadır: limonu, şekeri, okumayl, zobay1 "sobayı" (Gümüş, 2017: 62). Boyabat ağzında da ek aynı şekilde dudak uyumuna bağlanmıştır: orayı, Ceyhunu, yaşımı (Akgül, 2019: 55).

Eski Anadolu Türkçesinde sürekli düz ünlülü kullanılan bu ekin, Batı Karadeniz bölgesi ağızlarında yuvarlak ünlülü şekilleri görülmektedir. Ancak bu kullanım bölgede sadece Bolu ili ağzında tespit edilmiştir. Bölgenin kalan ağız bölgelerinde söz konusu ek dudak uyumuna bağlanmıştır.

\section{6. İyelik Eki 3. Teklik Şahıs: $+I /+s I$}

Eski Anadolu Türkçesinde iyelik ekleri dönemin genel yuvarlaklaşma eğilimi doğrultusunda birinci ve ikinci şahısların bağlantı ünlüleri yuvarlaktır, üçüncü şahıslarda ise düz ünlülüdür: ‘ anber ķok,usl, eger gündüz yarasanuñ gözi görmezse güneşüñ günāhl yok, anlaruñ bir dilkü ķonşılarl varıdı (Akar, 2018: 136-137).

Batı Karadeniz bölgesinde bu ekin düz ünlülü tabanlarda yuvarlak ünlülü şekilleri kullanılmaktadır. Bolu ili ağzında ek dudak uyumuna bağlı kullanılsa da ekin uyum dışı yuvarlak ünlülü şekilleri görülür: yapduğunu, cāmisü, hepüsünü, arkasunda, bağlarunıñ (Öztürk, 2019a: 77). Kastamonu ağzında ek tamamen dudak uyumuna bağlı durumdadır: ucunu, mezesinden, ocaķları (Acar, 2012: 139-141). Düzce ili Kaynaşlı ilçesi Yeniyurt ve Altınköy ağızlarında dudak uyumuna bağlanmıştır: ķocası, üçü, ķızı, halleri (Gümüştel, 2019: 51-53) Zonguldak-Bartın-Karabük illeri ağızlarında ek dudak uyumuna bağlıdır: gocası, köyü, köyi, badalyası "madalyası", mantosu, uşakları (Eren, 1997: 4-50). Sinop-Ayancık ilçesi ağzında ek dudak uyumuna bağlıdır: amcasını, kilosu, gemisi, büyükleri, çilelerini (Gümüş, 2017: 65). Boyabat ilçesi ağzında ise dudak uyumu dışında 
yuvarlak ünlülü nadiren kullanılmaktadır: anası, abasunun "ablasının", türküsü, evleri, çiçekleri (Akgül, 2019: 53).

Eski Anadolu Türkçesinde sürekli düz ünlülü kullanılan teklik üçüncü şahıs iyelik eki, Batı Karadeniz bölgesi ağızlarında yuvarlak ünlülü şekilde nadiren kullanılmıştır. Dudak uyumu dışında yuvarlak ünlülü kullanımlar Bolu ve Sinop-Boyabat ilçesi ağızlarında tespit edilmiştir.

\section{7. Şahıs Eki (2. Teklik ve 2. Çokluk Şahıs): -sIn/-sIz}

Bu ekler, Eski Anadolu Türkçesinde sürekli düz ünlülü kullanılan zamir kökenli şahıs ekleridir: yohssa biri birine bag̀larsın edyān gerekür, çün muhammed yolını başarasız, görisersin hoş durur senüñ işüñ, devece böyümişsin, cānum alasın, bu resme niçe görmişsiz işi siz (Akar, 2018: 165-166).

Batı Karadeniz bölgesi ağızlarında bu ekin yuvarlak kullanımları görülmektedir. Bolu ili ağzında ek genel olarak dudak uyumuna bağlı kullanılmak; ancak nadiren düz ünlülü tabanlarda yuvarlak ünlülü kullanımları da mevcuttur: alısuñ "alırsı", deyesuñuz "diyesiniz", okuyorusuñuz "okuyorsunuz", büyütmüşsün (Öztürk, 2019a: 94). Kastamonu ağzında ek dudak uyumuna bağlı durumdadır: gelmişsiñiz, dutmuşsuñuz, gelmişsiñ (Acar, 2012: 217-218). Düzce ili Kaynaşl1 ilçesi Yeniyurt ve Altınköy ağızlarında yuvarlaklaşma nedeniyle uyum dışı kullanımlar görülmektedir: biliysüñ, biliysü̈̈z, yaparsuñ (Gümüştel, 2019: 79-81). Zonguldak-Bartın-Karabük illeri ağızlarında ek dudak uyumuna bağlıdır: almalısiñ, örtmelisiñ, gideceksiñiz, çıkarasıñız (Eren, 1997: 63). SinopAyancık ilçesi ağzında dudak uyumuna bağlıdır: gatıcakssıñ, naparsınız (Gümüş, 2017: 85, 89). Boyabat ilçesi ağzında ise nadiren yuvarlaklaşma görülmektedir: ayırısuñuz "ayırırsınız", darılısuñuz "darılırsınız" (Akgül, 2019: 60-61).

Eski Anadolu Türkçesinde sürekli düz ünlülü kullanılan ek, Batı Karadeniz bölgesi ağızlarında genellikle dudak uyumuna bağlı kullanılmıştır. Sadece Bolu, Düzce-Kaynaşlı ilçesi Yeniyurt ve Altunköy köyleri ve Sinop-Boyabat ilçesi ağızlarında nadiren yuvarlak ünlülü kullanımları bulunmaktadır.

\section{Sonuç}

Ağızlar dil çalışmalarına kaynaklık eden çok önemli hazineleridir. Bugün yazı dilinde bulunmayan; fakat tarihî dönemlerde var olduğunu bildiğimiz pek çok fonetik özellik, morfolojik yapı, söz varlığı unsuru ağızlarda varlı̆̆ını sürdürebilmektedir. O sebeple dil çalışmalarında ağızlar ile tarihî dönemler arasında sıkı bir ilişki bulunmaktadır.

Eski Anadolu Türkçesi, Türkçenin tarihî dönemleri içerisinde ünlü yuvarlaklaşmasının en fazla görüldüğü dönemdir. Özellikle sürekli yuvarlak ünlülü kullanılan ekler, düz ünlülü tabanlara eklendiğinde dudak uyumu bozulmaktadır. Bu sebeple Eski Anadolu Türkçesinde dudak uyumu çok düşük seviyededir. Dönemin bu özelliği bugün Batı Karadeniz bölgesi ağızlarında da görülmektedir. Bölge içerisinde yer alan Bolu, Düzce, Kastamonu, Zonguldak, Bartın, Karabük, Sinop illeri ağzılarında ünlü yuvarlaklaşması ağız özelliği olarak korunmuştur. Hatta Eski Anadolu Türkçesinde düz ünlülü kullanılan bazı eklerin Batı Karadeniz bölgesi ağızlarında yine dudak uyumu dışında yuvarlak şekilde kullanıldığı görülmüştür.

Eski Anadolu Türkçesi ile Batı Karadeniz bölgesi ağızlarının her ikisinde de yuvarlak ünlülü kullanılan ek sayıs1 16 olarak tespit edilmiştir. Bu 16 ekin tamamı bölge ağızlarının bütününde yuvarlak ünlülü kullanılmamakta; ancak bölgenin ekseriyetinde yuvarlak ünlülü olarak görülmektedir. 7 ek ise Eski Anadolu Türkçesinde sürekli düz ünlülü kullanılırken Batı Karadeniz bölgesinde dudak uyumu dışında yuvarlak ünlülü kullanılmaktadır.

Hem Eski Anadolu Türkçesi hem de Batı Karadeniz bölgesi ağızlarında yuvarlak ünlülü tespit edilen eklerden bölgenin genelinde yuvarlak ünlülü kullanılanlar şunlardır: $+c U k$ isimden isim 
yapım eki, $-d U r$ - fiilden fiil yapım eki, $-d U k$ sıfat-fiil eki, $-g U$ fiilden isim yapım eki, $+l U$ isimden isim yapım eki, $+s U z$ isimden isim yapım eki, $-U r$ geniş zaman eki ve $-U z$ birinci çokluk şahıs eki. Yuvarlak ünlülü eklerin bölge ağzı içerisinde en çok görüldüğü yerler Bolu ve Kastamonu ağızlarıdır.

Eski Anadolu Türkçesinde sürekli düz ünlülü kullanılan eklerden $+l I k$ isimden isim yapım eki ile - $m I S ̧$ öğrenilen geçmiş zaman ekinin yuvarlak ünlülü ve dudak uyumu dışında kullanımı Batı Karadeniz bölgesi ağızlarının ekserisinde görülmektedir. Bu başlıkta sıralanan diğer ekler bölgenin ekserisinde değil, muhtelif ağız bölgelerinde görülmektedir. Eski Anadolu Türkçesinde düz ünlülü olup bölge ağzında yuvarlak ünlülü kullanılan ekler en çok yine Bolu, daha sonra da Sinop-Ayancık ve Boyabat ağızlarında görülmektedir.

Batı Karadeniz bölgesi ağızları ünlü yuvarlaklaşması yönünden incelendiğinde bölge ağzı ile Eski Anadolu Türkçesi arasında benzerlik olduğu görülmektedir. Özellikle Bolu ağzı bu anlamda öne çıkmaktadır. Tabii Eski Anadolu Türkçesinin yazı dili olmasında bölge ağzının katkı sunup sunmadığını sadece bu ağız özelliğini dikkate alarak cevaplamak mümkün değildir. Ancak bu çalışmanın yazı dili-ağız çalışmalarına en azından bir katkı vereceği düşüncesindeyiz.

\section{Kaynakça}

Acar, E. (2012). Kastamonu ve yöresi ağızları, Yayınlanmamış doktora tezi, Trakya Üniversitesi Sosyal Bilimler Enstitüsü, Türk Dili ve Edebiyatı Ana Bilim Dalı, Türk Dili Bilim Dalı, Edirne.

Akar, A. (2018). Oğuzların dili eski Anadolu Türkçesine giriş, Ötüken Neşriyat.

Akca, H. (2016). Ankara ili ağızları ile Eski Anadolu Türkçesinin ünlü yuvarlaklaşması bakımından karşılaştırılması", Gazi Türkiyat, Bahar 2016, S. 18, 93-109.

Akgül, Z. (2019). Sinop ilinin Boyabat ilçesi ăgzl, Yayınlanmamış yüksek lisans tezi, Selçuk Üniversitesi Sosyal Bilimler Enstitüsü Türk Dili ve Edebiyatı Ana Bilim Dalı Türk Dili Bilim Dal1, Konya.

Çamurcu, D. (2011). Zonguldak merkez ă̆zı (inceleme, metinler, sözlük), Yayınlanmamış yüksek lisans tezi, Doğu Akdeniz Üniversitesi Lisansüstü Eğitim, Öğretim ve Araştırma Enstitüsü Türk Dili ve Edebiyatı Dalı, Gazimağusa, Kuzey Kıbrıs.

Develi, H. (1995). Evliya Çelebi Seyahatnamesine göre 17. yüzyll Osmanlı Türkçesinde ses benzeşmeleri ve uyumlar, Türk Dil Kurumu Yayınları.

Ercilasun, A. B. (2005). Başlangıçtan yirminci yüzyıla Türk dili tarihi, 2. Baskı, Akçağ Yayınları.

Eren, M. E. (1997). Zonguldak-Bartın-Karabük illeri ağızları, Türk Dil Kurumu Yayınları.

Ergin, M. (2012). Türk dil bilgisi, Bayrak Basım/Yayın/Dağıtım.

Gülsevin, G. (2017). Eski Anadolu Türkçesinde ekler, 4. Bask1, Türk Dil Kurumu Yayınları.

Gümüş, E. M. (2017). Sinop ili Ayancık ilçesi ağzı, Yayınlanmamış yüksek lisans tezi, Aksaray Üniversitesi Sosyal Bilimler Enstitüsü Türk Dili ve Edebiyatı Ana Bilim Dalı, Aksaray.

Gümüştel, Z. (2019). Düzce ili Kaynaşlı ilçesi Yeniyurt ve Altunköy köyleri ă̆ızları, Yayınlanmamış Yüksek Lisans Tezi, Erciyes Üniversitesi Sosyal Bilimler Enstitüsü Türk Dili ve Edebiyatı Ana Bilim Dalı Türk Dili Bilim Dalı, Kayseri.

Karahan, L. (1996). Anadolu ağızlarının sınıflandirılması, Türk Dil Kurumu Yayınları. 
Batı Karadeniz Bölgesi Ağızları ile Eski Anadolu Türkçesindeki Eklerin Ünlü... 441

Karahan, L. (2006). Eski Anadolu Türkçesinin kuruluşunda yazı dili-ağız ilişkisi, Turkish Studies, 1/1 Summer 2006, 1-12. http://dx.doi.org/10.7827/TurkishStudies.4

Kartallığlu, Y. (2007). Tanzimat gramerlerinde bazı eklerin imlası ve dudak uyumu ile ilgili uyarılar, Bilig, Güz 2007, S. 43, 85-106.

Korkmaz, Z. (1994). Bartın ve yöresi ă̆ızları, Türk Dil Kurumu Yayınları.

Korkmaz, Z. (2013). Türkiye Türkçesinin temeli Oğuz Türkçesinin gelişimi, Türk Dil Kurumu Yayınları.

Korkmaz, Z. (2014). Türkiye Türkçesi grameri şekil bilgisi, 4. Bask1, Türk Dil Kurumu Yayınları.

Öztürk, E. (2019a). Bolu ili ă̆ızları, 2. Baskı, Akçă̆ Yayınları.

Öztürk, E. (2019b). Gerede ağzında ünlü yuvarlaklaşmaları üzerine, Tarih Okulu Dergisi, Aralık 2019, S. XLIII, 1852-1861. http://dx.doi.org/10.29228/joh.39611

Sümer, F. (1972). Oğuzlar (Türkmenler) tarihleri-boy teşkilatı-destanlarl, 2. Bask1, Ankara Üniversitesi Dil ve Tarih-Coğrafya Fakültesi Yayınları

Timurtaş, F. K. (2012). Eski Türkiye Türkçesi, Kapı Yayınları.

Tulum, M. (2011). 17. Yüzyıl Türkçesi ve söz varlı̆̆g, Türk Dil Kurumu Yayınları.

Yelten, M. (2009). Eski Anadolu Türkçesi ve örnek metinler, İstanbul Üniversitesi Edebiyat Fakültesi Yayınları. 